Bill for placing the appointment of certifying surgeons in the hands of the millowners, subject to the control of the magistrates; and your petitioners, \&c.

\section{RESPIRATION OF THE INFANT.}

To the Editor.-Sir : At page 48 of $\mathrm{THE}$ Lancet, for April 8th, Mr. Semple, in some pertinent remarks on the hydrostatic test, observes, that "the principal objection is, that the lungs may float from putrefaction as well as from the presence of respired air." I trust that he and your numerous readers will pardon me for calling attention to the following passage in Beck's work on "Medical Jurisprudence," page 271 of the fifth edition:- "If lungs of this description (i.e., ina state of putrefaction), or any portions of them, be squeezed in the hand, they will immediately sink in water. On the contrary, no compression, however strong, can force out so completely the air from lungs that have respired as to cause them to sink." Some years since I witnessed a series of experiments on this subject, the results of which most satisfactorily corroborated the opinion of the above-named eminent authority. I have the honour to be, Sir, your obedient servant,

\section{Suffolk-place, Lower Islington,}

J. Brown.

$$
\text { April 13, 1843. }
$$

P.S. It appears to me that vaginal respiration will in future be the great stumbling block to convictions for infanticide.

\section{FEVER IN ST. GILES'S INFIR M A Y Y.}

To the Editor of THE LANCET.

SrR,-My attention having been directed to some contradictory statements in the daily journals, as to the unusual prevalence of fever in the parish of St. Giles-in-the-Fields, and finding that one of them, at least, is very inaccurate, $\mathrm{I}$ beg to forward an authentic statement on the subject for insertion in your columns, deeming them a better channel for communication on such a matter than the newspapers.

On the 24th of April there were thirtyfour cases of fever in the wards of our infirmary, five of which were true typhos, and twenty-nine continued fever, of a low typhoid type, the majority of which cases have been unusally severe in their symptoms, but are now recovering.

It will be seen from the subjoined table that the number of fever cases during the last three months has been considerably Jarger than in any three months of the preceding year. In fact, it nearly equals the total amount of cases in 1842 .

The mortality in 1843 , although comparatively large, still does not afford a proper estimate, as it was judged prudent to send off our worst cases to the Fever and Middlesex Hospitals (principally to the former).

$\begin{array}{ccc}\begin{array}{c}\text { Cases taken } \\ \text { into }\end{array} & \begin{array}{c}\text { Cases } \\ \text { attended }\end{array} \\ \text { Infirmary. } & \text { at Home. } & \text { Dent to } \\ \text { Hosp. }\end{array}$

Jan. . $15 \ldots \ldots \ldots 3 \ldots \ldots$

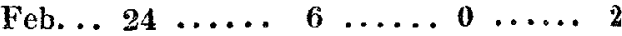

March $19 \ldots \ldots .5 \ldots 5$

April . $25 \ldots \ldots .3 \ldots \ldots 2$

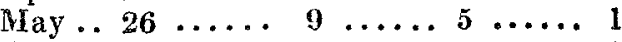

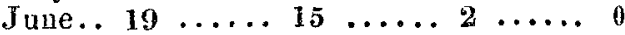

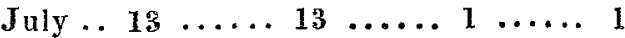

August $16 \ldots \ldots 18 \ldots \ldots 2 \ldots 2$

Sept... $5 \ldots \ldots .5 \ldots \ldots 2$

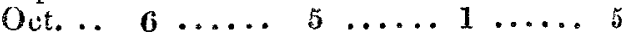

Nov. .. $13 \ldots \ldots \ldots 22 \ldots 14$

Dec... $25 \ldots \ldots .23 \ldots \ldots .6 \ldots 12$

$\begin{array}{llll}206 & \overline{132} & \overline{25} & \end{array}$

1843.

Jan. . $43 \ldots \ldots .54 \ldots \ldots$. . . 515

Feb. . $30 \ldots \ldots 64 \ldots 6 . \ldots 606$

March $53 \ldots \ldots .77 \ldots \ldots 49$

$\begin{array}{llll}* 126 & \overrightarrow{195} & \overrightarrow{18}\end{array}$

The number of new cases is at present, I am happy to state, diminishing. I remain, Sir, your obedient servant,

JAMES REID, M.D.,

Physician to the Infirmary of

St. Giles and Bloomsbury.

10, Bloomsbury-square,

April 18, 1343.

\section{MEDICAL REPORT}

OF THE SUPERINTENDING COMMITTEE OF THE PENITENTIARY AT MILBANK.

In the course of last year an epidemic of a formiclable character prevailed in the institution. Several cases of severe dysentery, attended with fever and inflammation, occurred during the month of Jauuary; but it was not until the 10th of February that they became very frequent, so as to constitute an epidemic Down to about the midale of March the disease continued to spread rapidly; and on the 16 th of that month there were 110 patients in the infirmaries, nearly all suffering from dysentery in different stages. When the epidemic was at its height the committee called in the profes. sional aid of Dr. Geolge Burrows, one of the physicians of St. Bartholomew's Hospital, who attended all the cases daily for a week, and subsequently visited the severer cases on alternate days for a fortnight. Towards the close of March the epidemic gradually declined, and at the commencement of April had entirely ceased. During April, May, Inne, and the greater part of July, the prison was tolerably healthy; but at the end

*33 typhus cases.

+39 typhus. 